\title{
Evaluation of e-commerce location and entry to China - implications on shipping and trade
}

Yulia Panova ${ }^{1}$, Albert Tan ${ }^{2}$, Olli-Pekka Hilmola ${ }^{3,5^{*}}$, M. H. Puvindran ${ }^{2}$, Xu Hongsheng ${ }^{1,4}$ and Weidong Li ${ }^{5}$

\author{
* Correspondence: olli-pekka. \\ hilmola@lut.fi \\ ${ }^{3}$ LUT University, Kouvola Unit, \\ Prikaatintie 9, FIN-45100 Kouvola, \\ Finland \\ ${ }^{5}$ School of Economics \& \\ Management, Beijing Jiaotong \\ University, Beijing 100044, China \\ Full list of author information is \\ available at the end of the article
}

\begin{abstract}
E-commerce is experiencing strong global growth, and leading market is nowadays that of China, whether it is evaluated from the perspective of domestic market size or cross-border volumes. In this research work further understanding and knowledge is built from Chinese market using general choice algorithm (GCA) and two real-life case studies. The outcome of GCA model shows the list of the most preferable locations for e-commerce enterprise development. Findings of this study are also compared to two case studies of e-commerce entrance to Chinese market, where one of these two is operating in an omnichannel environment. Market entrance in these two was implemented through very simplified and centralized distribution structure, and using location of Shanghai. Actual operations are either outsourced or in-house produced. Cash on delivery (COD) is still the preferred payment method in e-commerce order fulfilment. One factor being rather important in case companies was distribution prices, where courier services all over the country play an important role. For logistics in general, and sea ports, research reveals that currently dominating areas of the Pearl and Yangtze River Delta face the challenge to some extent from other places of China as favourable locations for e-commerce and consumption are also at north and western parts.
\end{abstract}

Keywords: E-commerce, Omnichannel, Decision-making, Warehouses, China

\section{Introduction}

China, being the world's largest e-commerce market, exceeding \$ 1.15 trillion (Acolink.com 2018; Vc.ru 2018), will continue significantly contribute to the growth of global retail ecommerce sales - including desktop and mobile commerce, which made up to $10.2 \%$ of total retail sales worldwide in 2017 (in 2015, this figure was 7.4\%; Emarketer.com 2018). The Digital analytics firm eMarketer projects that online retail sales will more than double between 2015 and 2019 and account for more than 12\% of global retail sales by 2019 (Emarketer.com 2015). Regardless that the online retail ecosystem is evolving fast, the convergence between online and offline shopping behaviour remains one of the topical issues among researchers and professionals (Rigby 2011; Wei et al. 2018). Particularly, the location selection is a significant problem that needs to be addressed (Giuffrida et al., 2017). For example, only the right location of bonded warehouses (e.g. in cross-border comprehensive e-

(c) The Author(s). 2019 Open Access This article is distributed under the terms of the Creative Commons Attribution 4.0 International License (http://creativecommons.org/licenses/by/4.0/), which permits unrestricted use, distribution, and reproduction in any medium, provided you give appropriate credit to the original author(s) and the source, provide a link to the Creative Commons license, and indicate if changes were made. 
commerce zones) can reduce the delivery time to 5 days, compared to the direct shipping model that requires 7-30 days for delivery (China-briefing.com, 2016).

With the notion of the cycles in the market economy (manufacturing-distributionconsumption), the right evaluation of factors that favour the integrated development of offline and online channels in e-commerce is essential. Many authors studied this topic, identifying the factors that influence e-commerce development (Hilmola and Tolli 2018; Hongfei 2017; Sedyh 2016; Hänninen et al. 2017). However, research requires broader analysis of supply chain designing in e-commerce cross-border trade (Chinabriefing.com, 2016; Logisticstime.com 2018). This type of e-commerce takes place between companies/consumers mainly of neighbouring countries without the need of physical travel across the borders for buying/selling activities. China's market is already responsible for $40 \%$ of overall e-commerce transactions globally (Acolink.com 2018). A growth rate of Chinese cross-border e-commerce has been impressive, on the average being more than 30\% p.a. in 2010-2016 (Hongfei 2017).

In the past, e-commerce saw slower growth than current levels mainly for two reasons: Shipping costs were added to order costs and there was a reluctance to divulge credit card information (Jacobsen 2014). However, consumer concerns waned as online sales grew rapidly, doubling in the 2011-2014 period (Jacobsen 2014). Two studies were conducted to understand the shift in customer tendency to "try" new ways of shopping in particular, the market for online shopping (Meuter et al. 2005). The outcome of the studies showed a correlation between role clarity, motivation and ability of usage of online ordering. This means that customers who understand the process of online ordering and have access to the Internet may opt for this model instead of the classical brick and mortar retail model (Meuter et al. 2005).

From a logistics point of view, however, the growing number of channels (online and offline) also increases complexity (Handfield et al. 2013). The fulfillment process is no longer linear, because brick and mortar retailing increasingly overlaps with distance retail (Beck and Rygl 2015). In the past, supply chain management was responsible for delivering goods to a retail store with the store being the end point of the transaction (Baird and Kilcourse 2011). Online retailing has now placed distribution systems on the front line, since retailers need to offer a variety of options for finding, buying, and returning goods (Mercier et al. 2014; Bell et al. 2014, Giuffrida et al., 2017). This topical issue partly can be considered in terms of the location problem (Farahani and Hekmatfar 2009). In this regard, different methods are available (the analytic hierarchy process, linear, non-linear programming, greenfield analysis, network optimization experiments, etc.), which proved their applicability to identical problems in scholar studies (Van Thai \& Grewal, 2005; Tantsuyev, 2012; Żak and Węgliński, 2014; Kayikci 2010).

This research work consists of two parts: (1) it contains analytical model using pairwise comparison, which is based on second-hand data arising from number of different sources and (2) case study to confirm, if the reasons from general choice algorithm (GCA) are consistent to validate the model. The considered model uses this data to build-up information concerning better cities to locate e-commerce and omnichannel warehousing and supply chain operations in China.

Yin (2003: 40-47) suggests case selection based on the following criteria. A single case can serve as a critical example (1) if it forms an extreme or unique case, e.g. if not many cases are available; (2) if it forms a typical or representative case, standing as an 
example of a wider group of cases; (3) if it is a revelatory case, where the investigator has an opportunity to observe and analyze a phenomenon so far inaccessible to scientific investigation; (4) if it provides a longitudinal case studying two or more points in time; or (5) if it stands as a pilot in a multi-case setting. In contrast, multiple cases often use a replication logic, but can also be used to select typical cases within a certain domain (Eisenhardt 1989). In our case, we have chosen two case studies completed in China, where two key persons were interviewed from these reported companies (rather typical case amount as compared to large-scale analysis of Hilmola, 2018). Company interaction and interviews took place during June-Sept.2017. Interviews were part of larger assignment, which was examining Asian retail market through case studies. Research regarding to cases is used here to serve the understanding of Chinese market, and it is descriptive with systems approach. Chinese retail market has become increasingly important over the years as in largest cities (so called tier 1 cities) purchasing power (especially in purchasing power parity terms) has improved to the level of old west (e.g. regional GDP in 2017 in Beijing, Shanghai and Tianjin was around 20,000 USD per person; Babones 2018). Tan et al. (2014) research work indicated in logistics industry responses that some Chinese cities, like Shenzhen or Shanghai, could even act as regional distribution centers of Asia.

The purpose of this study is to evaluate the e-commerce enterprise location in China. In this regard, this article answers the following research questions: 1) What are the success factors of e-commerce zones in China? and 2) Which locations are favourable for omnichannel shoppers' development? To reveal the essence of the research, the study is structured as follows: In Section 2, several theories have been considered to create the framework for studying the e-commerce enterprise location in China. Section 3 provides systematization of factors that support the choice for favourable Chinese provinces, which were ranked based on general choice algorithm. After these, in Section 4, two completed case studies are analyzed together, which give perspective for theoretical second-hand data based evaluation model. In final Section 5, we conclude study, and provide avenues for further research.

\section{Theoretical background}

\section{Relevance of international trade models and transport cost theories}

E-commerce is one of the prospering and competitive spheres of businesses in China (Ecommerceworldwide.com 2017; Hänninen et al. 2017; Hilmola and Tolli 2018). Jiang and Prater (2002) correctly estimated that e-commerce adaptation would take time from Chinese logistics system and infrastructure, however, once done, it would change significantly this country. The long-term expectations for this digital market remain high not only within one country, but across the global market, where a full potential is far from being realized, especially in the sphere of cross-border trade. Absolute ecommerce cross-border trade was estimated to be 6.66 trillion yuan (around one trillion USD) in 2016, and this mostly to export direction (Hongfei 2017). Based on the statistics of China's Custom, absolute e-commerce cross-border trade is 8.06 Trillion yuan in 2017 (approximately 1.2 trillion USD). In the first half of 2018, absolute ecommerce cross-border trade reaches 4.5 trillion yuan (almost 0.67 trillion USD; 100ec.cn 2019). One of the driving factors of its growth is in the development of 
platform-based services (Fu et al. 2018), and particular, shopping platforms of Alibaba Group, such as Aliexpress, Pandao, Joom, Wish that are used in Russia. For some other foreign markets is used Lazada in Vietnam, Indonesia, Malaysia, Singapore and the Philippines, as well as widespread growth of mobile users contributing to m-commerce evolvement.

The current study looks into the invisible part of the online trade, such as logistics, purchasing and distribution practices, as well as initial manufacturing phases that represent the offline side of omnichannel shoppers and should be considered from an integral point of view (Tarn et al. 2002). Before any goods (tangible or intangible) appear on the company's websites and purchased by consumers, they have to be produced, undergo the value-added operations and then delivered to the required locations. Forward-thinking companies may be aware of this need for simultaneous developments, but do not know where to start and make the right decisions on the online business development that drive margin and profitability growth in both channels.

One of the sources for gaining financial benefits is hidden in the economic concept, which dates back to Smith (1937). In particular, the economies of scale theory can be applied to a variety of organizational and business situations, because when the economy of scale is realized, the economic growth can be achieved. According to the theory, when average costs starts falling as output increases, then economies of scale are occurring. For doing so, it is possible to purchase inputs at a lower per-unit cost when they are purchased in large quantities, or use other sources of economies. For example, in wholesale and retail distribution, the increase of the speed of operations, such as order fulfilment, can lower the overall costs of doing business. Continuing notions from the landmark book of A. Smith 'The Wealth of Nations' (1776), where transport supports the trade in goods on the national level, the article takes logistics and trade perspective under the focus.

Logistics is considered as indispensable part of studies on location of e-commerce enterprises (Wei et al. 2018; Li et al. 2014, Giuffrida et al., 2017). For example, the research on dual-channel pricing under deterministic demand discusses the various logistical determinants of price (Wei et al. 2018). Authors, in turn, apply location-based pricing of a food retail company taking into account spatial distribution of customers on logistics costs, customers' channel preference and service providers' pricing. Li et al. (2014) studied the phenomenon of returns in e-commerce through the locationinventory problem, which was solved by lagrangian relaxation combined with ant colony algorithm (LRCAC). XiaoYan et al. (2012) also developed reverse logistics network model, but under the assumption of uncertain demand and return. Other recent studies (He et al. 2017; Lu et al. 2011) likewise focus on logistics-oriented decisions for online shopping, providing location orientation of E-shops and joint distribution center by a new hybrid fuzzy multiple-criteria decision-making methods.

\section{Basic approaches for the analysis of international e-commerce}

Apart from logistics and supply chain theories, the feasibility studies on the ecommerce enterprise location in China include other well-tested approaches and methods of scientific analysis. Due to the fact that omnichannel enterprises in crossborder trade are represented by large ecosystems processing of goods in international 
trade, the explanation of the arrangement of their multi-functional structure must be found additionally in the theories of trade and transport cost theories (Fig. 1). Specifically, the figure schematically shows the relationship of the basic approaches that were taken into consideration to justify the Chinese provinces advantageous for omnichannel shoppers (Brynjolfsson et al. 2013; Verhoef et al. 2015; Hübner et al. 2016), with the allowance for logistics and trade perspective of cross-border trade.

Despite the fact that some of the theories could be called by the authors as approaches or simple models, they are still fundamental in the international business (Chapter 6, International Trade Theory, Hill and Hult 2018). For the development of trade theory, first and foremost, Smith (1937) made significant contribution. Adam Smith argued that countries should specialize in production of goods for which they have absolute advantage (e.g. French in production of wine). Depending on countries absolute advantages in producing specific types of products, it is possible to find out what products are profitable to export and what is useful to import. On the other hand, countries should import products, which can be made with lower cost in the partner country. Specifically, David Ricardo's theory of comparative advantage took one step further from A. Smith's theory, suggesting in his book 'Principles of Political Economy' (1817) that countries should specialize in the production of those goods they produce most efficiently and buy goods they produce less efficiently from other countries. These theories include many unrealistic assumptions and naturally have a lot of limitations that make them suitable mainly for explaining trade flows between the nations (Chapter 6, International Trade Theory, Hill and Hult 2018, p. 130).

Unlike Ricardo's theory, the Heckscher-Ohlin argues that the pattern of international trade is determined by differences in factor endowments (like land, labour, and capital), rather than differences in productivity. Thus, Swedish economists Eli Heckscher (in 1919) and Bertin Ohlin (in 1933) put forward a different explanation of comparative advantage (Hill and Hult 2018). Another famous Harvard strategy professor, Michael Porter, has also written extensively on international trade. Porter theorizes that four broad attributes (factor endownments; demand conditions; related and supporting industries; firm strategy, structure, and rivalry), constituting a diamond, bring the creation of competitive advantage ('The Competitive Advantage of Nations', Porter, 1990). In the framework of Porter' work "National Demand of Competitive advantage", Chen and Ning (2002) evaluated China's progress towards building electronic commerce.

It should be noted that these international trade theories, at the same time, have important implications for business practice (location, first-mover, and government policy implications). Specifically, many economists believe and stress in their classical trade

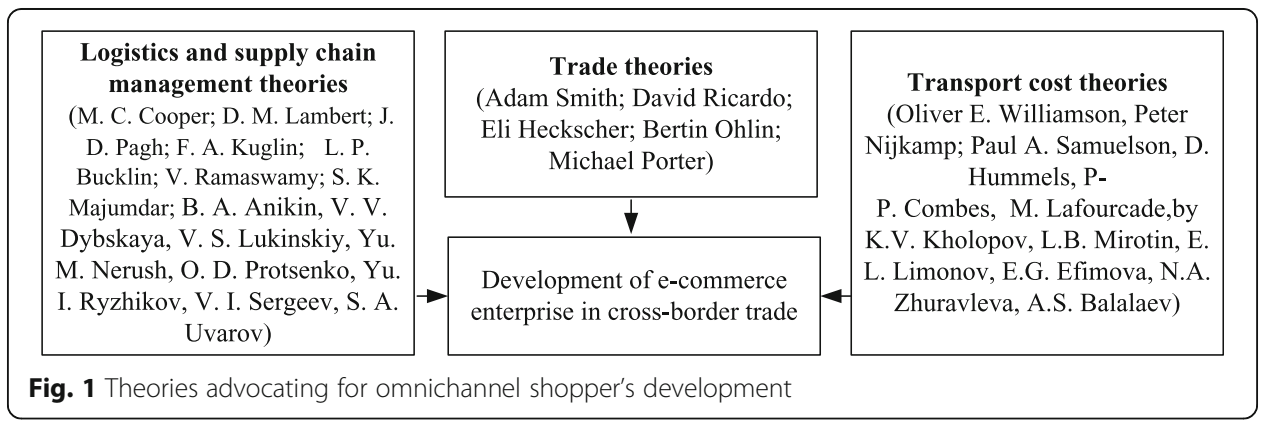


theories (Smith, Ricardo, and Heckscher-Ohlin) that unrestricted free trade between nations will raise the economic welfare of countries, which participate in a free trade system. In light of current governmental policy, e.g. tariffs, subsidiaries, import quotas, export restraints, local content requirements, administrative policies, and antidumping duties, which frequently intervene and influences the international trade, the attention should be drawn to benefits of the free trade explained by the theories (higher level of domestic consumption, more efficient utilization of resources that stimulate growth and creation of wealth of nations). Still, the critics, for example from Paul Samuelson, show that free trade has historically benefited rich countries (Hill and Hult 2018, p. 133), and, of course, the political reality of international trade is beyond from the books' models and approaches.

Moreover, in the works of authors on international trade the attention to transport costs and related barriers is scarce. Meanwhile, transport significantly determines the trade in goods and services, therefore, the location of e-commerce enterprise was considered with the accessibility to the transport infrastructure and with the allowance for transport costs. Economic analysis of the transport sector is elaborated in the works of Oliver E. Williamson and Peter Nijkamp, theoretical and empirical studies of transport costs were provided by Paul A. Samuelson, D. Hummels, P-P. Combes and M. Lafourcade, while Russian school in the sphere of transport and logistics is represented by K.V. Kholopov, L.B. Mirotin, E. L. Limonov, E.G. Efimova, N.A. Zhuravleva, and A.S. Balalaev (Chernyavskaya 2016).

Further on, going down from the national level to the regional, the omnichannel ecosystem was regarded as a network of various companies, referring to logistics and supply management theory (Cooper et al. 1997; Kuglin 1998; Bucklin et al. 1996, Lukinskiy, 2007). The question of the formation of the scientific base of the integrated supply chain management is reflected in many works of B. A. Anikin, V. V. Dybskaya, V. S. Lukinskiy, L. B. Mirotin, Yu. M. Nerush, O. D. Protsenko, Yu. I. Ryzhikov, V. I. Sergeev, S. A. Uvarov and others (Lukinskiy et al. 2017). The theories of logistics and supply chain management are correlated with the 40 theories of marketing, management and organization theory (Miles 2012).

The scientific basis for the management of material, information, financial, service and personnel flows is, first of all, is grounded on models and methods of the theory of logistics, management and marketing (Lukinskiy et al. 2017): transport models; network models; deterministic and probabilistic models of dynamic programming; deterministic and probabilistic models of inventory management; Markov decision-making processes; Queuing systems; theory of games and decision-making, respectively, in terms of certainty, risk, uncertainty; simulation modeling; method of dynamics of averages; forecasting methods.

\section{Location problem and multi-criteria decision-making methods}

To define the advantageous location of the enterprise in the sphere of e-commerce cross-border trade, depending on the type or complexity of location problem (single facility location problem, multi-facility allocation or location-allocation problem; Farahani and Hekmatfar 2009) different methods can be applied (e.g. linear, non-linear programming, simplex algorithm, lagrangian relaxation, branch \& cut methods, branch and 
bound, local beam search, tabu search, artificial neural network, expert systems, fuzzy control, generic algorithms, multi-agent systems, and so on; Kayikci 2010). In the current study, the general choice algorithm is applied, which was for the first time proposed by Lukinskiy et al. (2012) and further used by Lukinskiy and Lukinskiy (2015) for the selection of intermediaries in the supply chain. In the earlier publication, Lukinskiy and Katkova (2014) provided the comparative evaluation of the analytic hierarchy process (AHP), point-rating assessment method (PRA) and proposed general intermediaries' choice algorithm (ICA).

According to the authors (Lukinskiy and Lukinskiy 2015; Lukinskiy and Katkova 2014), the ICA method is more difficult than the PRA one, but its objectivity is higher. At the same time, the ICA method produces almost the same evaluations as the AHP method does. In spite of AHP method popularity (Saaty 1994; Önden et al. 2016), it is often criticized because of a series of drawbacks (Aly and Vrana 2008; Berardi 2017). It allows some small inconsistency in augments because human is not always consistent, therefore, there is an inability to adequately handle the inherent uncertainty with the AHP method. Moreover, the AHP method possesses an advantage only when there is no any quantitative (tangible) information except for the experts' evaluations (Lukinskiy and Lukinskiy 2015; Lukinskiy and Katkova 2014). In the below analyses, the tangible information was collected about all relative factors for the choice of alternatives.

The choice was made among 31 Chinese provinces based on the 15 factors that were partly mentioned in the similar studies (Panova and Hilmola, 2018): (1) Number of cross-border e-commerce zones, (2) Access to the sea, (3) Number of postal offices, (4) Number of outlets for express services, (5) Length of postal routes, (6) Retail purchase value, (7) Retail sales value, (8) Retail stock value, (9) Number of corporate enterprises of retail trade, (10) Number of websites, (11) Number of Internet users, (12) Broadband subscribers port of Internet, (13) Labour productivity, (14) Wages level, and (15) Unemployment rate.

For multi-criteria decision-making, the general choice algorithm (GCA) was used to rank the most advantageous regions for the development of e-commerce enterprise. GCA, as AHP, is grounded on the pairwise comparison. In a pairwise comparison, two alternatives are compared according to criterion and one is preferred. The objective of AHP is to choose the best alternative. The decision maker selects the alternative that best meets the decision criteria. As a rule, the general mathematical process includes several steps. In the first step, it is required to mathematically determine preferences (e.g. for the site) with respect to each criterion. In the second step, mathematically identify preferences for criteria (rank order of importance). Then, combine these two sets of preferences to mathematically derive the composite score for each site. Finally, select the site with the highest score.

According to GCA, at the beginning, the criteria should be divided into three groups: quantitative, qualitative and relay (or 'killer-evaluation'). Then, the pairwise comparison is used to rank the criteria. Quantitative data processing is carried out by the qualimetry methods, and to obtain quality criterion values authors suggested to use Harrington desirability function (Lukinskiy and Lukinskiy 2015). The calculation of the integral estimates is a sum of qualitative and quantitative criteria evaluation. In the current research, all data were of the quantitative nature, which again justifies the use of GCA, because AHP method 'possesses substantial advantages without having any quantitative 
(tangible) information except for the experts' evaluations' (Lukinskiy and Lukinskiy 2015).

GCA and AHP both utilize pairwise comparison. In this regard, GCA is similar to AHP. Pairwise comparison was carried out based on the mathematical steps. Firstly, a pairwise comparison matrix for each decision alternative for each criterion was developed. Afterwards, the synthesization was done in several sub-steps. That is the row value of the pairwise comparison matrix was summed up in the last column. Next, the sum of the last column was found. Afterwards, each value in last column was divided by its column sum. Finally, the value in each row of normalized matrices was averaged, and the sum of the row averages in the normalized matrix equaled to 1 . The row average values represented the preference vector. Preference vectors for other criteria are computed similarly, resulting in the preference matrix (that is step 1 in AHP).

As a result, the final criteria preference matrix was used for the overall ranking for the decision alternatives, assuming the equal importance of the criteria. So, with GCA, preferences for the site with respect to each criterion were determined mathematically. GCA did not utilize preference scale, which assigns numerical values (as a rule, from 1 to 9) to different levels of importance. GCA did not resort to preference scale for pairwise comparison because quantitative (tangible) information was available for each criterion. In conclusion, it is worth to mention that the research was partly done in the Henan Key Laboratory for Big Data Processing \& Analytics of Electronic Commerce, which has an affiliation to Luoyang Normal University.

\section{E-commerce enterprise development in the prominent regions of China}

According to Digital analytics firm eMarketer (Emarketer.com 2018), an improving export business, higher employment and wages as well as rising e-commerce and crossborder sales across Asia-Pacific, North America and Western Europe were all factors in driving retail spending. Thus, the location of omnichannel shoppers is determined by multi-criteria that support online and offline trade development. The factors for such decisions are mainly related to the economic benefits of both enterprises and mentioned in earlier research (Panova and Hilmola, 2018): (1) National economic; (2) Industrial; (3) Logistical; (4) Economical; and (5) Regulative.

Many sub-factors influence the location decision. Their relevance depends on the scope of the location problems (whether it is viewed from international, national, statewide or communitywide level; Farahani and Hekmatfar 2009). From the international level, factors such as the access to the natural resources, provision of labour forces, foreign exchange rate, business climate, components of the multiplier effect, inflation level, duties and taxes are essential. If the scope of location problem is narrower, then the factors like property tax incentive, government regulations, transport tariffs, the selling price of goods, and business climate on local basis play a role (Chen and Ning 2002; Jennex et al. 2004). Authors stress that the development of technical infrastructure and regulatory frameworks stimulate e-commerce growth.

The research of critical e-commerce factors in France by Colla and Lapoule (2012) revealed that an integrated multichannel approach for online business requires more differentiated logistical system and improved customer relations marketing. The number of internet users in less developed provinces was considered as a constraint for ecommerce growth (Chen and Ning 2002). Meanwhile, Internet usage is beginning to 
increase outside of the wealthy and educated urban elite as more people go online in China. The overall trend of the expected growth of middle- and upper-income categories to some 190 million by 2020 from 17 million in 2010 makes the whole market attractive for foreign direct investments. Unlike a few decades ago when low-cost production attracted companies to enter the market, nowadays, the consumption forecast opens up new opportunities due to triple growth of Chinese economy during 2000 to 2010 (Hill and Hult 2018). So as to identify the most attractive region for the investors in China, 15 factors were chosen (Fig. 2) for the general choice algorithm.

In support of e-commerce enterprise location in China, governmental regulations trigger the business activity at local level in many regions. In particular, the government of China develops comprehensive cross-border e-commerce zones. These zones are designated exclusively for the development of cross-border e-commerce industry, as they target preferential tax policies and streamlined customs clearance procedures (Chen and Ning 2002). Such zones have been developed in three stages, starting from zone Hangzhou, home to the e-commerce giant Alibaba that was established in 2015 (first phase). The latest, third phase, which was announced recently, in July 2018 foresees the creation of the additional 22 zones; Acolink.com 2018). Thus, according to Acolink.com (2018), in China, 35 cross-border ecommerce zones will be developed. Their location in regard to 22 Chinese provinces, as well as to five Autonomous Regions (Inner Mongolia, Guangxi, Tibet, Ningxia, and Xinjiang) and four Chinese municipalities (Beijing, Shanghai, Tianjin, and Chongqing), which are under the direct administration of central government,

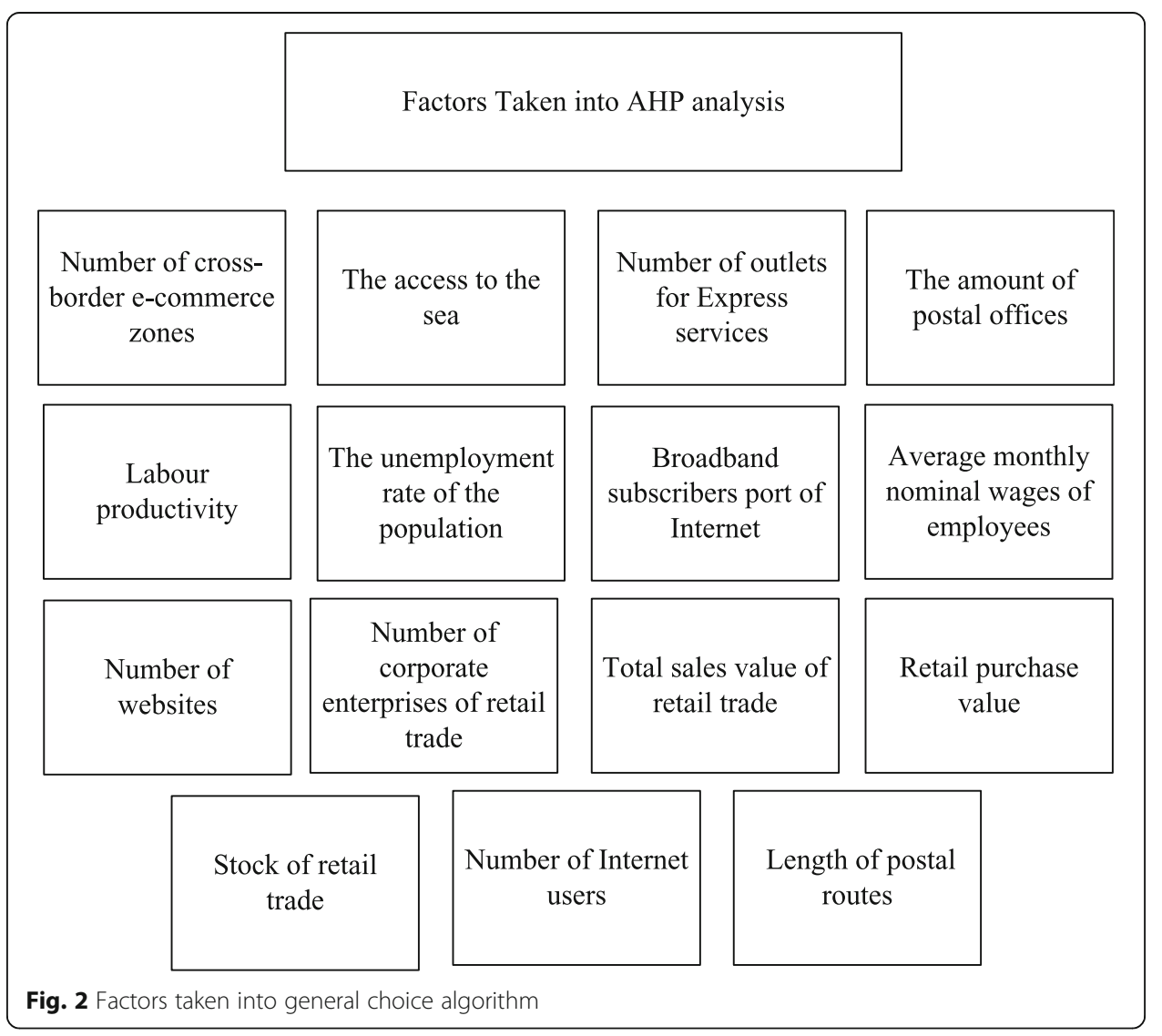


Table 1 Provinces of China with cross-border comprehensive e-commerce zones (number of zones in each province; Acolink.com 2018)

\begin{tabular}{|c|c|c|c|}
\hline Province & $\begin{array}{l}\text { Administrative } \\
\text { center }\end{array}$ & $\begin{array}{l}\text { Number of Zones (*E-commerce } \\
\text { development plan) }\end{array}$ & $\begin{array}{l}\text { Row average values from } \\
\text { normalized matrix }\end{array}$ \\
\hline Anhui & Hefei & 1 & 0.027 \\
\hline Fujian & Fuzhou & 1 & 0.027 \\
\hline Gansu & Lanzhou & 1 & 0.027 \\
\hline Guangdong & Guangzhou & 4 & 0.108 \\
\hline Guizhou & Guiyang & 1 & 0.027 \\
\hline Hainan & Haikou & 1 & 0.027 \\
\hline Hebei & Shijiazhuang & 1 & 0.027 \\
\hline Heilongjiang & Harbin & 1 & 0.027 \\
\hline Henan & Zhengzhou & 1 & 0.054 \\
\hline Hubei & Wuhan & 1 & 0.027 \\
\hline Hunan & Changsha & 1 & 0.027 \\
\hline Jiangsu & Nanjing & 3 & 0.081 \\
\hline Jiangxi & Nanchang & 1 & 0.027 \\
\hline Jilin & Changchun & 1 & 0.027 \\
\hline Liaoning & Shenyang & 2 & 0.054 \\
\hline Qinghai & Xining & 0 & 0.000 \\
\hline Shanxi & Taiyuan & 0 & 0.000 \\
\hline Shandong & Jinan & 2 & 0.054 \\
\hline Shaanxi & Xi'an & 1 & 0.027 \\
\hline Sichuan & Chengdu & 1 & 0.027 \\
\hline Yunnan & Kunming & 1 & 0.027 \\
\hline Zhejiang & Hangzhou & 3 & 0.081 \\
\hline Beijing & Beijing & 1 & 0.027 \\
\hline Shanghai & Shanghai & 1 & 0.027 \\
\hline Tianjin & Tianjin & 1 & 0.027 \\
\hline Chongqing & Chongqing & 1 & 0.027 \\
\hline $\begin{array}{l}\text { Inner } \\
\text { Mongolia }\end{array}$ & Hohhot & 1 & 0.027 \\
\hline Guangxi & Nanning & 1 & 0.027 \\
\hline Tibet & Lhasa & 0 & 0.000 \\
\hline Ningxia & Yinchuan & 0 & 0.000 \\
\hline Xinjiang & Urumchi & 1 & 0.027 \\
\hline
\end{tabular}

Entries in boldface are largest values to identify highest performing regions

has been summarized in Table 1. Additionally, at this table, the "E-commerce development plan" in Xinjiang is depicted. According to Hongfei (2017), this plan was designed to facilitate exports to the Middle East and East Asia. Hongfei (2017) also noted that Guangxi Province promoted cooperation between China and Vietnam through E-commerce trade and cooperation. Heilongjiang Province listed the Suifenhe border economic cooperation zone as a base of cross-border ecommerce development and focused on opening cross-border trade with Russia. Recent news also mentioned about the creation of free trade zone in Luoyang in addition to already established zone in Zhengzhou (M.sohu.com 2017). 
The availability and closeness to these zones is essential in terms of logistics processes. Specifically, the bonded warehouse model can be used for the delivery of the products to final clients from abroad. Investors may set up a warehouse within their respective e-commerce zone. Goods will then be transported and stored temporarily within the warehouse under the Customs supervision, before they are delivered to domestic customers. In this case, the delivery time can be reduced to 5 days, compared to the direct shipping model that requires 7-30 days for delivery (China-briefing.com, 2016). The reason for long deliveries is that under the direct sale model, foreign manufacturers maintain warehouses in their home countries and send goods to customers after they have made orders online that involves a relatively more complicated customs clearance procedure. As can be seen from Table 1 and after a provided pair-wise comparison, the most preferred regions are Guangdong, Jiangsu, and Zhejiang while Qinghai and Shanxi regions are less prioritized by the criterion of e-commerce zones availability.

Apart from the regulative preferences, it is essential to take into account the potential basic conditions for the developing of the online retail trade. For these reasons, total sales and purchases value of retail trade, as well as a number of corporate enterprises of retail trade and stock of retail trade across Chinese provinces have been analyzed by the pair-wise comparison. The total purchases value refer to the total value of purchases of commodities by enterprises (establishments) from other establishments or individuals (including direct import from abroad) for the purpose of re-selling, either with or without further processing of the commodities purchased. Sales value of retail trade refers to the value of commodities sold by the establishments to other establishments and individuals. The commodities include: (1) commodities sold to urban and rural residents and social groups for their consumption; (2) commodities sold to establishments in all industries for their production and operation, including commodities sold to wholesale and retail establishments for re-selling, with or without further processing; and (3) commodities for direct export to abroad.

The value of commodities stock imply the total amount of commodities possessed by wholesaler and retailer of various types of registration status, including different types of stocks: (1) located in storage, garages, counters, and shelves of operating places of wholesale and retail trades (such as sale stores, wholesale centers, procurement stations and operating offices); (2) commodities in the process of being selected, sorted, and packed; (3) commodities not arrived but recorded as purchase in the account; and (4) commodities purchased for other units, but not delivered yet, etc. The figures for the analyses (i.e. total sales and purchases value of retail trade, as well as a number of corporate enterprises of retail trade and stock of retail trade) were obtained from China's National Bureau of Statistics (2018). However, due to the reason of text volume restriction, only the outcome from the processed initial data is represented in Table 2 .

In the analysis of basic conditions of retails trade among the Chinese provinces, an outstanding concentration of retail purchase, sales, and stock values can be noticed in four regions (Guangdong, Jiangsu, Shandong, and Shanghai; Table 2). The availability of stock values also may indicate the potential availability of warehousing capacity in these provinces. Large warehouses are necessary, if the deliveries are done over long distances. Well-developed transport infrastructure is also important as the main 
Table 2 Basic conditions of retail trade (purchases, sales, and stock values)

\begin{tabular}{|c|c|c|c|c|}
\hline \multirow[t]{2}{*}{ Province } & \multicolumn{4}{|l|}{ Preference vectors for the criteria } \\
\hline & $\begin{array}{l}\text { Number of corporate enterprises of retail trade } \\
\text { (Unit) }\end{array}$ & $\begin{array}{l}\text { Sales value } \\
\text { (Yuan) }\end{array}$ & $\begin{array}{l}\text { Purchase value } \\
\text { (Yuan) }\end{array}$ & $\begin{array}{l}\text { Stock Value } \\
\text { (Yuan) }\end{array}$ \\
\hline Beijing & 0.020 & 0.063 & 0.069 & 0.057 \\
\hline Tianjin & 0.012 & 0.025 & 0.023 & 0.015 \\
\hline Hebei & 0.026 & 0.026 & 0.027 & 0.028 \\
\hline Shanxi & 0.021 & 0.000 & 0.016 & 0.022 \\
\hline $\begin{array}{l}\text { Inner } \\
\text { Mongolia }\end{array}$ & 0.014 & 0.014 & 0.013 & 0.012 \\
\hline Liaoning & 0.025 & 0.027 & 0.026 & 0.025 \\
\hline Jilin & 0.018 & 0.016 & 0.015 & 0.013 \\
\hline Heilongjiang & 0.013 & 0.014 & 0.013 & 0.013 \\
\hline Shanghai & 0.019 & 0.057 & 0.053 & 0.086 \\
\hline Jiangsu & 0.087 & 0.093 & 0.092 & 0.092 \\
\hline Zhejiang & 0.057 & 0.066 & 0.064 & 0.069 \\
\hline Anhui & 0.047 & 0.033 & 0.033 & 0.031 \\
\hline Fujian & 0.057 & 0.038 & 0.036 & 0.030 \\
\hline Jiangxi & 0.024 & 0.016 & 0.016 & 0.034 \\
\hline Shandong & 0.088 & 0.084 & 0.087 & 0.062 \\
\hline Henan & 0.080 & 0.046 & 0.045 & 0.038 \\
\hline Hubei & 0.052 & 0.060 & 0.062 & 0.058 \\
\hline Hunan & 0.048 & 0.037 & 0.036 & 0.047 \\
\hline Guangdong & 0.086 & 0.101 & 0.095 & 0.105 \\
\hline Guangxi & 0.020 & 0.014 & 0.014 & 0.019 \\
\hline Hainan & 0.002 & 0.004 & 0.004 & 0.005 \\
\hline Chongqing & 0.035 & 0.031 & 0.029 & 0.021 \\
\hline Sichuan & 0.046 & 0.047 & 0.048 & 0.035 \\
\hline Guizhou & 0.021 & 0.014 & 0.013 & 0.013 \\
\hline Yunnan & 0.023 & 0.020 & 0.020 & 0.018 \\
\hline Shaanxi & 0.034 & 0.028 & 0.028 & 0.027 \\
\hline Gansu & 0.011 & 0.010 & 0.010 & 0.008 \\
\hline Qinghai & 0.002 & 0.002 & 0.002 & 0.002 \\
\hline Tibet & 0.001 & 0.001 & 0.001 & 0.001 \\
\hline Ningxia & 0.003 & 0.003 & 0.003 & 0.003 \\
\hline Xinjiang & 0.009 & 0.008 & 0.008 & 0.011 \\
\hline
\end{tabular}

Note: In parenthesis, the units are for the initial values of data processed in pair-wise comparison Entries in boldface are largest values to identify highest performing regions

prerequisite for faster deliveries. Therefore, further on, the group of transport factors will be considered.

It should be noted that the goods that are sold via the online trading platforms are subject to the so-called parcel deliveries. That is why potential foreign investors, planning to operate businesses in China should be aware of logistics provides, such as SF Express, STO Express, YTO Express, and ZTO Express and their outlets for express services. These four companies now represent over $80 \%$ of the express delivery market share in China (International Trade Centre 2016). Additionally, availability of postal offices and postal delivery routes allocation across Chinese provinces influence the 
decisions. Postal routes imply the connections between the post offices, post offices and agencies, agencies and railway stations, docks, airports, and transfer stations. By the modes of transport, the postal routes can be divided into airmail postal routes, railway postal routes, car postal routes, waterway postal routes and others, and can be analyzed in details from the website of National Bureau of Statistics (2018). In the current analysis, only the total length of postal routes was considered (Table 3).

The results of the analysis show that logistics infrastructure for parcel delivery is better developed in Guangdong, Zhejiang, Sichuan, Shandong, Jiangsu and Hubei (Table 3), and therefore, these regions are more advantageous for e-commerce enterprise development,

Table 3 Pair-wise comparison of provinces (logistics infrastructure for parcel deliveries)

\begin{tabular}{|c|c|c|c|}
\hline \multirow[t]{2}{*}{ Province } & \multicolumn{3}{|c|}{ Preference vectors for the criteria } \\
\hline & $\begin{array}{l}\text { Number of postal offices } \\
\text { (unit }{ }^{\mathrm{a}} \text { ) }\end{array}$ & $\begin{array}{l}\text { Number of outlets for express services } \\
\left(\text { unit }^{a}\right)\end{array}$ & $\begin{array}{l}\text { Length of postal routes } \\
\left(\mathrm{km}^{\mathrm{a}}\right)\end{array}$ \\
\hline Beijing & 0.033 & 0.004 & 0.091 \\
\hline Tianjin & 0.009 & 0.011 & 0.021 \\
\hline Hebei & 0.030 & 0.003 & 0.023 \\
\hline Shanxi & 0.028 & 0.003 & 0.015 \\
\hline $\begin{array}{l}\text { Inner } \\
\text { Mongolia }\end{array}$ & 0.019 & 0.021 & 0.040 \\
\hline Liaoning & 0.027 & 0.032 & 0.042 \\
\hline Jilin & 0.017 & 0.025 & 0.019 \\
\hline Heilongjiang & 0.022 & 0.026 & 0.023 \\
\hline Shanghai & 0.035 & 0.047 & 0.036 \\
\hline Jiangsu & 0.060 & 0.066 & 0.031 \\
\hline Zhejiang & 0.055 & 0.071 & 0.105 \\
\hline Anhui & 0.035 & 0.042 & 0.009 \\
\hline Fujian & 0.034 & 0.039 & 0.035 \\
\hline Jiangxi & 0.030 & 0.026 & 0.014 \\
\hline Shandong & 0.047 & 0.052 & 0.067 \\
\hline Henan & 0.050 & 0.045 & 0.023 \\
\hline Hubei & 0.055 & 0.055 & 0.027 \\
\hline Hunan & 0.037 & 0.042 & 0.015 \\
\hline Guangdong & 0.100 & 0.132 & 0.068 \\
\hline Guangxi & 0.028 & 0.029 & 0.038 \\
\hline Hainan & 0.008 & 0.009 & 0.014 \\
\hline Chongqing & 0.023 & 0.022 & 0.021 \\
\hline Sichuan & 0.076 & 0.071 & 0.041 \\
\hline Guizhou & 0.028 & 0.029 & 0.015 \\
\hline Yunnan & 0.029 & 0.029 & 0.042 \\
\hline Shaanxi & 0.030 & 0.026 & 0.032 \\
\hline Gansu & 0.021 & 0.024 & 0.029 \\
\hline Qinghai & 0.005 & 0.004 & 0.014 \\
\hline Tibet & 0.004 & 0.005 & 0.009 \\
\hline Ningxia & 0.006 & 0.004 & 0.008 \\
\hline Xinjiang & 0.018 & 0.006 & 0.031 \\
\hline
\end{tabular}

Note $^{a}$ : In parenthesis the units are for the initial values of data processed in pair-wise comparison Entries in boldface are largest values to identify highest performing regions 
especially when considering an invisible part of an online trade. However, not only logistics infrastructure, but also telecommunication development is critical for the doing of ecommerce businesses. Due to this fact, below is the analysis of main indicators of Internet provision. That is the broadband subscribers port of Internet, number of websites, and number of Internet users (Table 4).

As can be seen from Table 4, by the criterion of the Internet development, the most favourable regions are Guangdong, Shandong, Jiangsu, Zhejiang, Beijing, and Henan. Further on, the group of socio-economic factors that can be important for the enterprise arrangement from a financial point of view will be described. That is the level of wages, unemployment rate, and labour productivity. On the whole, wages are important for the investments in labour-intensive production, since it requires considerable labour

Table 4 Main indicators of Internet development

\begin{tabular}{|c|c|c|c|}
\hline \multirow[t]{2}{*}{ Province } & \multicolumn{3}{|l|}{ Preference vectors for the criteria } \\
\hline & Broadband subscribers port of Internet & Number of websites & Number of Internet users \\
\hline Beijing & 0.016 & 0.155 & 0.024 \\
\hline Tianjin & 0.010 & 0.013 & 0.014 \\
\hline Hebei & 0.054 & 0.032 & 0.055 \\
\hline Shanxi & 0.025 & 0.014 & 0.028 \\
\hline Inner Mongolia & 0.014 & 0.004 & 0.018 \\
\hline Liaoning & 0.033 & 0.030 & 0.038 \\
\hline Jilin & 0.015 & 0.007 & 0.020 \\
\hline Heilongjiang & 0.019 & 0.010 & 0.026 \\
\hline Shanghai & 0.021 & 0.025 & 0.025 \\
\hline Jiangsu & 0.090 & 0.065 & 0.063 \\
\hline Zhejiang & 0.073 & 0.085 & 0.051 \\
\hline Anhui & 0.036 & 0.017 & 0.038 \\
\hline Fujian & 0.039 & 0.073 & 0.037 \\
\hline Jiangxi & 0.028 & 0.009 & 0.028 \\
\hline Shandong & 0.080 & 0.069 & 0.072 \\
\hline Henan & 0.059 & 0.051 & 0.057 \\
\hline Hubei & 0.038 & 0.026 & 0.042 \\
\hline Hunan & 0.036 & 0.018 & 0.042 \\
\hline Guangdong & 0.094 & 0.185 & 0.112 \\
\hline Guangxi & 0.027 & 0.011 & 0.031 \\
\hline Hainan & 0.006 & 0.005 & 0.007 \\
\hline Chongqing & 0.024 & 0.013 & 0.022 \\
\hline Sichuan & 0.062 & 0.050 & 0.050 \\
\hline Guizhou & 0.015 & 0.004 & 0.021 \\
\hline Yunnan & 0.022 & 0.006 & 0.026 \\
\hline Shaanxi & 0.027 & 0.015 & 0.028 \\
\hline Gansu & 0.013 & 0.003 & 0.015 \\
\hline Qinghai & 0.003 & 0.001 & 0.004 \\
\hline Tibet & 0.001 & 0.000 & 0.002 \\
\hline Ningxia & 0.004 & 0.002 & 0.005 \\
\hline Xinjiang & 0.016 & 0.003 & 0.000 \\
\hline
\end{tabular}


capital, and regions with lower wages would be more favourable (Makarov 2011). However, for the omnichannel shop project, this factor is not so critical. The same can be applied to the labour productivity factor, i.e. the ratio of the gross regional product in current prices to the number of employees in the region. The other socio-economic indicator is the level of unemployment, which can be considered in a negative connotation. In particular, it was assumed that growth of the unemployment rate reduces purchasing and investment demand, production, therefore, if the unemployment rate goes down (like in Beijing), the higher is the overall points (Table 5).

Table 5 Indicators of socio-economic development

\begin{tabular}{|c|c|c|c|c|c|c|}
\hline \multirow[t]{2}{*}{ Province } & \multirow{2}{*}{$\begin{array}{l}\text { Wages } \\
\text { level } \\
\text { (Yuan) }\end{array}$} & \multirow{2}{*}{$\begin{array}{l}\text { Unemployment } \\
\text { rate (\%) }\end{array}$} & \multirow{2}{*}{$\begin{array}{l}\text { Labour } \\
\text { productivity } \\
\text { (Yuan/ } \\
\text { person) }\end{array}$} & \multicolumn{3}{|c|}{ Preference vectors for the criteria } \\
\hline & & & & $\begin{array}{l}\text { Wages level } \\
\text { (Yuan) }\end{array}$ & $\begin{array}{l}\text { Unemployment } \\
\text { rate (\%) }\end{array}$ & $\begin{array}{l}\text { Labour productivity } \\
\text { (Yuan/person) }\end{array}$ \\
\hline Beijing & 119928 & 1.4 & 324301.7 & 0.017 & 0.071 & 0.024 \\
\hline Tianjin & 86305 & 3.5 & 625275.8 & 0.024 & 0.028 & 0.047 \\
\hline Hebei & 55334 & 3.7 & 501398.5 & 0.037 & 0.027 & 0.038 \\
\hline Shanxi & 53705 & 3.5 & 303110.2 & 0.038 & 0.028 & 0.023 \\
\hline $\begin{array}{l}\text { Inner } \\
\text { Mongolia }\end{array}$ & 61067 & 3.7 & 618200.1 & 0.034 & 0.027 & 0.047 \\
\hline Liaoning & 56015 & 3.8 & 396989.6 & 0.037 & 0.026 & 0.030 \\
\hline Jilin & 56098 & 3.5 & 458693.2 & 0.037 & 0.028 & 0.035 \\
\hline Heilongjiang & 52435 & 4.2 & 362136.4 & 0.039 & 0.024 & 0.027 \\
\hline Shanghai & 119935 & 4.1 & 448861.9 & 0.017 & 0.024 & 0.034 \\
\hline Jiangsu & 71574 & 3 & 516852.2 & 0.029 & 0.033 & 0.039 \\
\hline Zhejiang & 73326 & 2.9 & 445368.4 & 0.028 & 0.034 & 0.034 \\
\hline Anhui & 59102 & 3.2 & 472055.3 & 0.035 & 0.031 & 0.036 \\
\hline Fujian & 61973 & 3.9 & 430760.9 & 0.033 & 0.026 & 0.033 \\
\hline Jiangxi & 56136 & 3.4 & 392368.5 & 0.037 & 0.029 & 0.030 \\
\hline Shandong & 62539 & 3.5 & 559660.5 & 0.033 & 0.028 & 0.042 \\
\hline Henan & 49505 & 3 & 353468.5 & 0.042 & 0.033 & 0.027 \\
\hline Hubei & 59831 & 2.4 & 454114.7 & 0.035 & 0.041 & 0.034 \\
\hline Hunan & 58241 & 4.2 & 555081.2 & 0.035 & 0.024 & 0.042 \\
\hline Guangdong & 72326 & 2.5 & 413037.1 & 0.029 & 0.040 & 0.031 \\
\hline Guangxi & 57878 & 2.9 & 456355.2 & 0.036 & 0.034 & 0.034 \\
\hline Hainan & 61663 & 2.4 & 400593 & 0.033 & 0.041 & 0.030 \\
\hline Chongqing & 65545 & 3.7 & 429679.1 & 0.032 & 0.027 & 0.032 \\
\hline Sichuan & 63926 & 4.2 & 418200.4 & 0.032 & 0.024 & 0.032 \\
\hline Guizhou & 66279 & 3.2 & 379307.2 & 0.031 & 0.031 & 0.029 \\
\hline Yunnan & 60450 & 3.6 & 352962.4 & 0.034 & 0.028 & 0.027 \\
\hline Shaanxi & 59637 & 3.3 & 379350.2 & 0.035 & 0.030 & 0.029 \\
\hline Gansu & 57575 & 2.2 & 275918.5 & 0.036 & 0.045 & 0.021 \\
\hline Qinghai & 66589 & 3.1 & 407749.2 & 0.031 & 0.032 & 0.031 \\
\hline Tibet & 103232 & 2.9 & 365411.0 & 0.020 & 0.038 & 0.028 \\
\hline Ningxia & 65570 & 3.9 & 448237.4 & 0.031 & 0.026 & 0.034 \\
\hline Xinjiang & 63739 & 2.5 & 301101.5 & 0.032 & 0.040 & 0.023 \\
\hline
\end{tabular}


It should be noted that Table 5 presents data on the average annual wages of employed persons in urban units across Chinese regions for the year 2016. The highest level of wages was recorded in the Beijing, Shanghai, and Tianjin (that is why these locations have the lowest scores. The lowest wages are identified in Henan, Heilongjiang, and Shanxi that therefore received the highest scores, according to GCA (Table 5). The unemployment rates are low in Beijing, Gansu, Hubei and Hainan, consequently, these sites are the most favourable by this criterion, while by the labour productivity (Table 5), Tianjin, Inner Mongolia, Shandong, and Hunan can be named as leading ones in the country.

Finally, the cumulative analysis of all the factors described before was provided. With the help of GCA, it was found that Guangdong province is the best for the ecommerce enterprise development as it obtained the highest score, compared to other locations (Table 6).

According to the final analysis, the rating of most beneficial regions for the development of e-commerce enterprise can be drawn. The list of ten preferable locations includes Guangdong, Jiangsu, Zhejiang, Shandong, Beijing, Henan, Fujian, Shanghai, Sichuan, and Hubei (Table 6). It should be noted that the three leading regions have the largest amount of e-commerce cross-border zones (four in Guangdong, three in Jiangsu and Zhejiang, Table 1). These are all located close to major container sea ports of the Pearl (e.g. Hong Kong, Shenzhen, and Guangzhou) and Yangtze River Delta (e.g. Shanghai, Ningbo, Suzhou, and Nanjing). However, fourth most beneficial region is Shandong, which is norther located as compared to the first three, and in their close proximity container sea ports are Qingdao, Lianyungang, and Tianjin. This again creates a challenge for currently dominating sea ports, they need to develop best connectivity e.g. with railway based container shuttles (or some other container sea port will do so as container sea ports among Chinese coastal line are numerous; see Li et al. 2019). Beijing (fifth) in turn is mostly connected to Tianjin sea port. Henan is sixth most attractive, and it is located at hinterlands (do note Sichuan in the ninth place). This again creates a challenge for currently dominating sea ports, they need to develop best connectivity e.g. with railway based container shuttles (or some other container sea port will do so as container sea ports among Chinese coastal line are numerous; see Li et al. 2019).

Based on the general choice algorithm (GCA) we tried to locate some e-commerce companies in the list of ten preferable locations to conduct interview to understand their supply chain network and their customer distribution. Eventually, two ecommerce companies located in Shanghai were willing to take part in this research.

\section{Two case studies}

Company A is an online private sales website for luxury lifestyle and fashion brands operating in Japan and China and expanded to Korea in 2012 (see Table 7 concerning supply chain information from two case studies completed). The company intends to sell online flash products (for a limited time) at a discounted price and a diverse range of luxury goods, which belong to five categories as follows: past season shoes, fashion, cosmetics, accessories, and leather goods. Company A rotates the brands it works with every week and will work with each brand 3-4 times per year. Since they began in early 2009 in Japan, Company A has developed working relationships with 450 brands. 


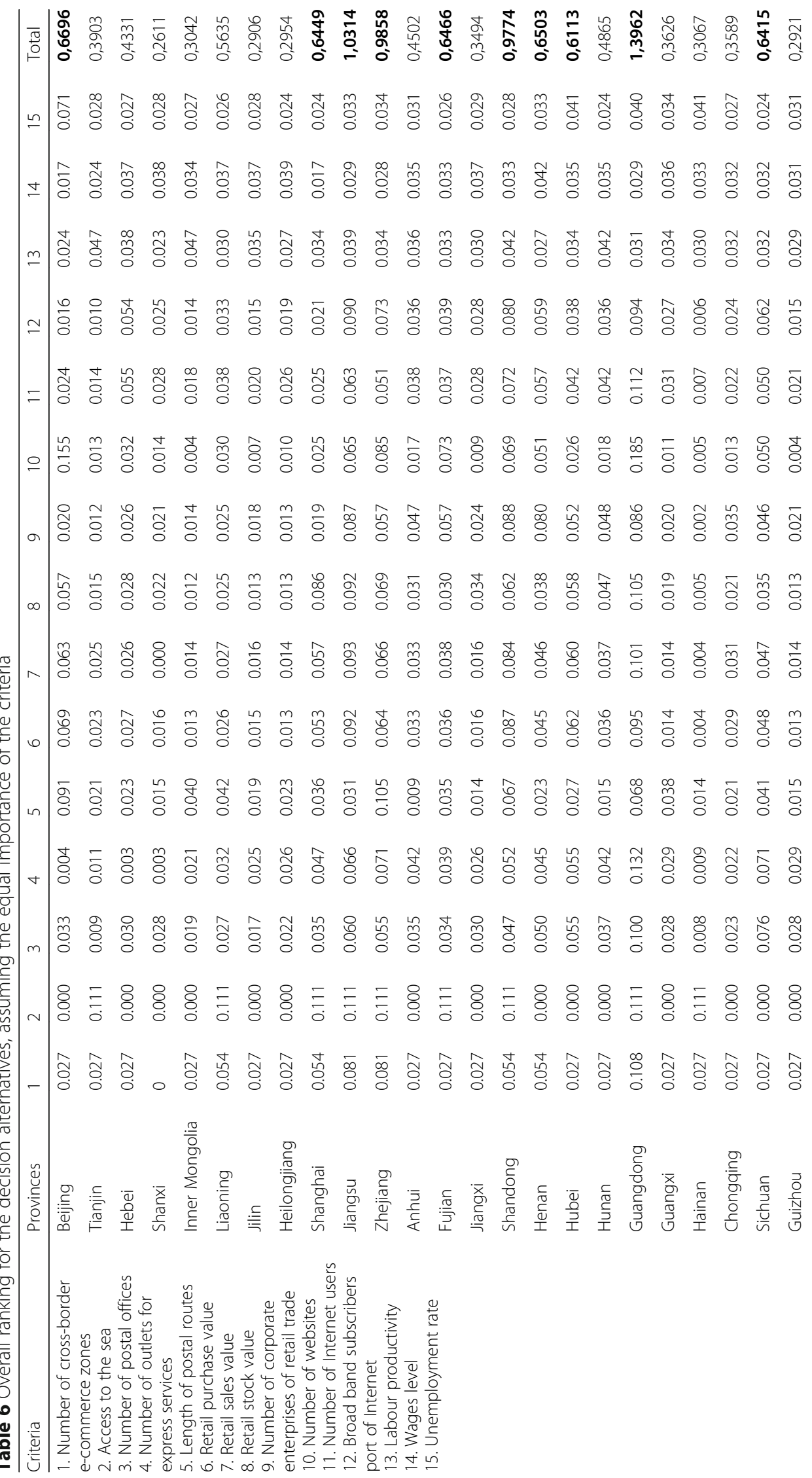




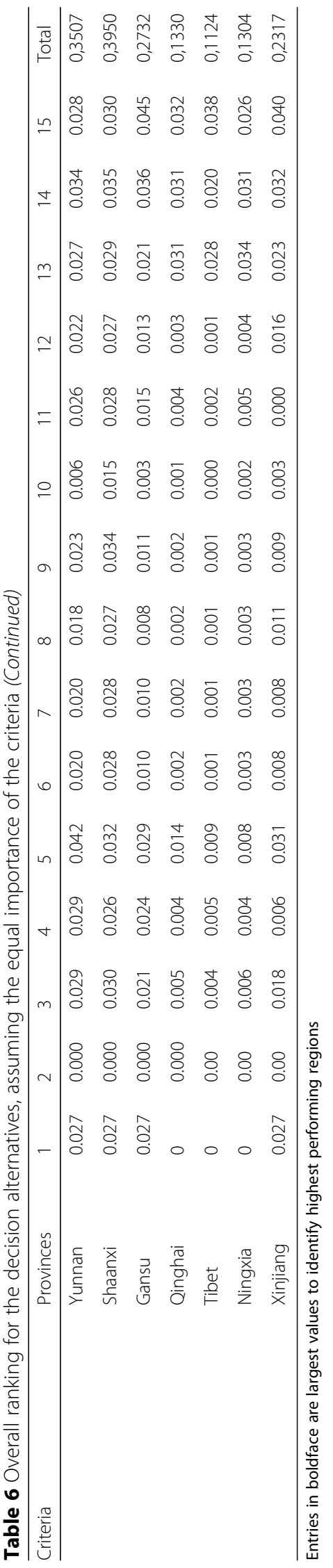


Table 7 Two companies operating in Chinese retail market and supply chain strategies

\begin{tabular}{|c|c|c|}
\hline & Company A & Company B \\
\hline Strategy & $\begin{array}{c}\text { Company A rotates the brands it works } \\
\text { with every week and will work with each } \\
\text { brand 3-4 times per year. }\end{array}$ & $\begin{array}{l}\text { Continue opening one store } \\
\text { every two weeks in China and } \\
\text { plans to continue this pace for } \\
\text { five years though there is a } \\
\text { presence in e-commerce }\end{array}$ \\
\hline Service Level & $\begin{array}{l}\text { Customer service team are their own } \\
\text { employees }\end{array}$ & $\begin{array}{l}\text { Offering free return, the } \\
\text { option for e-Commerce } \\
\text { customers to pick their orders } \\
\text { up in a store, repair and } \\
\text { cleaning services. Company B } \\
\text { also offers an expediting } \\
\text { service, but only if a customer } \\
\text { requests it. }\end{array}$ \\
\hline Distribution & $\begin{array}{l}\text { Outsourced-Centralized warehouse in } \\
\text { Shanghai }\end{array}$ & $\begin{array}{c}\text { Inhouse - } 2 \text { warehouses in } \\
\text { Shanghai }\end{array}$ \\
\hline Fulfillment & $\begin{array}{l}\text { offers next day and two day guaranteed } \\
\text { delivery }\end{array}$ & \\
\hline IT & $\begin{array}{l}\text { Has an integrated IT system that can } \\
\text { interface with all its fulfillment partners }\end{array}$ & \\
\hline
\end{tabular}

Service level is an important factor for the success of Company A and for this reason, all customer service is managed by its own employees. Company A has 35 dedicated customer service employees, who operate out of the warehouse. One unique market characteristic in China is a large number of orders that are paid for by cash on delivery (COD). For Company A, this constitutes half of its sales. Remarkably, its rejection rate, the rate at which customers either do not pay for the item upon delivery or are not there to pay for the product is less than $1 \%$. Customer service agents who actively reach out to customers to make sure they are informed about their purchase and delivery time. This customer-centric approach gives people confidence in their purchase and provides the comfort of knowing they are getting a quality product. Additionally, Company A will cover the cost of any returned product again easing any doubt for a customer to purchase a product.

For Company A, 40\% of its customers are based in China's tier 1 cities (Shanghai, Beijing, Guangzhou, and Shenzhen), 35\% are from tier 2 cities, and the remaining 25\% are scattered in tier three and four cities. Customers living in tier 1 cities are primarily business people with white-collar jobs and the customers residing in the remaining tier 2,3 , and 4 cities are entrepreneurs who are affluent, but do not have access to luxury goods. The age of Company A's customer base ranges from 25 to 40-year-olds, with $40 \%$ of them consisting of repeat customers. These customers purchase on average 900 RMB per transaction. One difference has been identified, and that relates to the average age of a customer. As shopping retail stores age was 35 years, but the average age shopping online was lower, 28 years old.

Company A currently operates a centralized warehouse based in Shanghai, China. The location in Shanghai allows it to closely monitor the quality control process and position itself to service the majority of its customers with short lead times. Company A has subcontracted its fulfillment operation to German-based 3PL that has been working in this market for a number of years. Third party operator is responsible for all the receiving, picking and packing, however, Company A has decided to keep all its 
customer service in-house. Company A holds its entire inventory on consignment with $90 \%$ of the goods coming from China and $10 \%$ being imported. Acquiring inventory on consignment allows Company A to keep its working capital free, manage obsolescence risk, and invest more in sales and marketing. By sourcing the majority of its products within China, Company A is able to keep ordering costs down and ensure the products meet customer preferences for local style, colour and size. Because Company A does not produce any of its own products, quality control is an important operation for the company. It checks every inbound piece and before the product is shipped to a customer, it ensures that the product meets the quality standards expected by Company A's customer. This process has proved beneficial as it achieved single-digit percentage in returns. However, as Company A continues to grow, it looks to introduce regional distribution centres and have suppliers ship directly to those warehouses thereby bypassing the central DC in Shanghai. Company A's warehouse expansion initiative will be guided by regional sales volume and customer profiling.

Company A's goal is to deliver all its products within 5 days and for large sales regions such as Shanghai and Beijing, Company A offers next-day and two-day guaranteed delivery. As a time to market is an essential component of handling a luxury service, Company A is looking to expand its warehouse footprint to three or four regional DC's that will be able to provide even faster time to market. At the moment, Company A is the collecting and analyzing sales data to decide, where and when it will open these regional distribution centres. For distribution, it uses two courier service providers, one local and one international, depending mostly on delivery costs (typically one provider is able to give good prices for a particular group of cities, but not for all).

The use of mobile technology varies in Asia and is quite different from that of the US or Europe. For example, 25\% of Company A's business in Japan comes through mobile e-commerce. Company A does not have available mobile e-commerce in China, but it is planning to in upcoming years and can expect to see similar sales patterns.

As Company A outsources its warehousing operations, the company does not have a single integrated IT platform. Company A does manage its e-commerce platform, allowing the company to manage its orders in real time.

To date, Company B has operated its e-Commerce business in Japan for 1 year and is working to launch in China as soon as possible. Working with luxury products has afforded Company B healthy margins. Therefore, any incremental supply chain costs the company incurs through its e-commerce operations will unlikely overshadow the incremental profits. The reason Company B has involved themselves in e-commerce business is simply, because the company is growing so fast in China that there are many other competing opportunities. Company B is opening one store every 2 weeks in China and plans to continue this pace for 5 years. This type of growth puts a strain on building the organizational capacity necessary for a different sales channel.

Asian markets are all the time evolving. For example, mobile technology is taking off in Japan and now constitutes 50\% of Company B's e-commerce sales. One of the striking differences between Japan and China is that in Japan, promotions do not play a large role in generating sales. Conversely, Chinese shoppers go online to find the best deal or a brand name product at a discount. In Japan, Company B is the number one brand in the number of bags sold and number two in value. 
In general, Company B prefers to keep its distribution and fulfillment operations inhouse, because it has a very high standard of service. From its experience managing a 3PL in the past, Company B has learnt that it can take just as much time to manage labour and operate the distribution and fulfillment themselves. For these reasons, it operates under a superstructure that will allow it to keep e-commerce distribution and fulfillment in-house, but will look at outsourcing options for potential fulfillment. The company has not yet completed an in-depth study of 3PL potential partners. It plans to examine, which companies' with other comparable brand are working with.

A unique characteristic of e-commerce in China is that the majority of consumers prefer to pay by COD rather than with credit cards. For products that that cost over $\$ 400$ USD, this becomes a risk. Therefore, the company has to ensure that the customer will be present and will be able to pay upon delivery. Fortunately, Company B has not experienced these problems in Japan as there are a number of steps a customer has to go through to complete an online transaction. Returns rates are quite low and Company B remains confident there will be a similar trend in China.

Another challenge associated with COD is that a trusted courier company in delivery and collection of cash in the various regions is critical. This remains difficult, because there is not a single courier service that can provide delivery to all postal codes; and the ones that reach more remote locations do not always provide the level of service Company B and its customers expect.

China is so vast that Company B does not expect to reach all the tier 3 and 4 cities. Instead, the company expects that the majority of their e-commerce business will come from cities they already have a presence. Company B currently has two warehouses in Shanghai, one of which is a bonded warehouse and the other is a duty paid warehouse. Its only other warehouse is in Hong Kong where currently, Company B runs half of its products through Hong Kong and the other half through the Shanghai warehouse. However, volume handled in Shanghai is growing at a much faster rate. In the medium and long-term as e-commerce is projected to grow in China, company is looking to couple its e-commerce inventory with that of retail and to develop a hub-and-spoke model with regional DC's located in the North, South, and West. This model will evolve over time.

\section{Conclusions}

In this study, we evaluated the e-commerce enterprise location in China with the allowance of cross-border trade and logistics perspective. The outcome of the study can be of interest for practitioners, who work on the convergence between online and offline shopping. The essence of the conducted analysis was unfolded through the two research questions. The answer to the first research question (What are the success factors of e-commerce zones in China?) was gained by the systematization of factors, taking into account international and national scopes of the problem. In particular, from the international level, factors such as political stability, access to natural resources, unemployment rate, foreign exchange rate, business climate, inflation level, duties and taxies are essential. If the scope of location problem is narrower, then the factors like number of cross-border e-commerce zones, wages level, transport tariffs, labour productivity, number of corporate enterprises of retail trade, and business climate on local basis play a role. 
The second research question (Which locations are favourable for omnichannel shoppers' development?) we narrowed down the decision analysis to 31 Chinese provinces. With the limited number of decision criteria (15 factors), the answer was found by of multi-criteria evaluation approach. The outcome shows that the most preferable locations are Guangdong, Jiangsu, Zhejiang, Shandong, Beijing, Henan, Fujian, Shanghai, Sichuan, and Hubei (Table 6). On the whole, the findings of our study may guide the investment funds of companies, who consider China as one of the several places, in which to invest. Also, the results of the study can strengthen the governmental support of the regions that are potentially favourable for e-commerce cross-border development with neighbouring countries. Therefore, from a practical point of view, our research facilitates the e-commerce start-ups, especially of those businesses that regard China ecommerce sphere as the top investment destination. Interestingly, most highly performing regions in pairwise comparison of GCA were very seldom showing low wages or exceptional labour productivity. However, highest performing locations were those, where Internet development was high, logistics infrastructure was advancing and supporting parcel deliveries, and retail trade was already showing its significance.

Two case studies completed for China- related retail operations, where Company A was already having e-commerce operations in this vast consumer market, while Company B was still relying on brick-and-mortar approach, while being launching ecommerce service in the near future. Both of these companies had chosen Shanghai as their main warehousing and logistics hub. However, as case studies indicated, this position is not static. Company A was planning to expand its warehousing network to other cities, as serving a larger number of cities requires this. Company B, in turn, has decided not to serve all cities, and was satisfied to current structure. Both cases illustrate the specifics of the Chinese retail market - both companies, A \& B, were still selling a lot of items with cash on delivery payment method, while Company B had found the demands and awareness of Chinese consumer. Cases also illustrate that producing services in-house is still very common (company A having customer service, and company B even warehousing and related functions), even if this is not necessarily lowest cost approach. Both companies were also forced to use number of different companies in parcel deliveries to reach different destinations in China.

Both empirical data parts of this research highlighted that old the Pearl and Yangtze River Delta centric warehousing model is about to change. These regions will of course hold important role in the future too, but further economic growth, growing cities in other parts of China, and favourable conditions in numerous different locations for ecommerce are drivers of change. It could be said based on this study that more northern and central parts of China will gain larger role in the future. This means that sea ports of this new emerging e-commerce regions shall gain some market share from currently dominating sea ports. This same finding is found in domestic logistics optimization models for lower $\mathrm{CO}_{2}$ emissions in China, where container sea ports play key role in import and export activity (Li et al. 2019). Another general finding arising from empirical part is the significance of information technology as well as supply chain management on overall performance, and location selection of e-commerce and omnichannel environment. In analyzed market it seemed to be the situation that low labour cost was not the main emphasis, but that of getting foothold in the growing markets, and assuring revenue growth. This is important finding for the e-commerce 
and omnichannel research as compared to earlier literature (Rigby 2011; Sedyh 2016; Hongfei 2017; Hänninen et al. 2017; Wei et al. 2018; Hilmola and Tolli 2018), but also for practice.

As further research, we would like to continue research work on Chinese omnichannel and e-commerce branch. One of the interesting avenues to follow would be the expansion of Chinese e-commerce companies to Russia and other near-by Eurasian countries. This includes also Europe, where expansion and deliveries could be supported with railway landbridges (Jiang et al. 2018; actually, railway based prompt delivery is already available in Alibaba offerings). Another avenue to follow is the expansion of retail operations to nearly 300 Chinese cities, which have a population of at least half a million. It is typically forgotten fact that China is having 15 megacities, but the amount of metro area cities is an overall 277 (OECD 2015).

\section{Acknowledgements}

Not applicable

\section{Authors' contributions}

Conceptualization, AT, O-PH, YP, XH, WL and PMH; Methodology, AT, YP and O-PH; Software, YP and O-PH; Validation, AT, WL, O-PH, YP, XH; Formal Analysis, AT, O-PH and YP; Investigation, AT, O-PH, YP, XH, WL and PMH; Resources, AT, $\mathrm{O}-\mathrm{PH}, \mathrm{YP}, \mathrm{XH}, \mathrm{WL}$ and $\mathrm{PMH}$; Writing-Original Draft Preparation, AT, O-PH, YP, XH, WL and PMH; Writing-Review \& Editing, AT, O-PH and YP; Visualization, O-PH, YP, PMH; Supervision, O-PH, AT and YP; Project Administration, O-PH. All authors read and approved the final manuscript.

\section{Authors' information}

PhD Yulia Panova is an Associate Professor at Luoyang Normal University in China. She used to work in National Research University Higher School of Economics and Emperor Alexander I St. Petersburg State Transport University, where she accomplished her post-graduate studies in 2012. In Lappeenranta University of Technology (Finland), she conducted Additional PhD research (2013-2016), concerning dry port public-private partnership investments and risk management methods. Miss Panova holds several international publications in the field.

Dr. Albert Tan is an associate professor in the Malaysia Institute of Supply Chain Innovation, Malaysia. His research interests are in reverse logistics, process modeling, re-engineering and information technology to coordinate supply chain. He holds an MBS from the National University of Ireland and a PhD in Supply Chain Management from the Nanyang Technological University. His research works have been published in numerous international journals and he also reviews papers for several international journals.

PhD Olli-Pekka Hilmola is working as a Professor in LUT University, in Kouvola, Finland. He is affiliated with numerous int. journals through editorial boards, including Industrial Management and Data Systems, Decision Support Systems, and Expert Systems with Applications. Dr. Hilmola has published more than 160 refereed journal manuscripts. He has been part of numerous international research projects. He is also currently serving as Visiting Professor in Beijing Jiaotong University.

Puvindran M.H. is M.Sc. student of Malaysia Institute for Supply Chain Innovation. Together with this he is also working with e-commerce and omnichannel adaptation and implementation in the emerging markets of Asia. Xu Hongsheng is an Associate Professor at Luoyang Normal University and Henan Key Laboratory for Big Data Processing \& Analytics of Electronic Commerce, China. He is an expert in artificial intelligence, data mining, knowledge discovery, the Semantic Web and has several international publications in the field of expertise.

PhD Weidong Li is working as an Associate Professor in Beijing Jiaotong University at School of Economics \& Management in Beijing, China. He is also currently Vice-Dean. Expertise of him includes economics and business administration together with quantitative modelling and analysis.

\section{Funding}

This research received no external funding.

\section{Availability of data and materials}

Contact corresponding author.

\section{Competing interests}

The authors declare that they have no competing interests.

\section{Author details}

${ }^{1}$ Luoyang Normal University, Luoyang 471934, China. ${ }^{2}$ Malaysia Institute for Supply Chain Innovation, No. 2A, Persiaran Tebar Layar, Seksyen U8, Bukit Jelutong, 40150 Shah Alam, Selangor, Malaysia. ${ }^{3}$ LUT University, Kouvola Unit, Prikaatintie 9, FIN-45100 Kouvola, Finland. ${ }^{4}$ Henan Key Laboratory for Big Data Processing \& Analytics of Electronic Commerce, Luoyang 471934, China. ${ }^{5}$ School of Economics \& Management, Beijing Jiaotong University, Beijing 100044, China. 
Received: 30 April 2019 Accepted: 10 July 2019

Published online: 31 July 2019

\section{References}

100ec.cn (2019). 2018 (Part I) Data monitoring report on China's cross-border e-commerce market. Available at: http://www. 100ec.cn/detail--6471917.html. Accessed 24 Jan 2019

Acolink.com (2018). China upgrades trade with 22 new comprehensive cross-border e-commerce zones. Available at: https:// www.acolink.com/news/2018/china-new-crossborder-ecommerce-zones-followup. Accessed 24 Jan 2019

Aly S, Vrana I (2008) Evaluating the knowledge, relevance and experience of expert decision makers utilizing the Fuzzy-AHP. Agric Econ 54(11):529-535

Babones S (2018) China quietly releases 2017 provincial GDP figures. Forbes 12 Feb 2018. Available at URL: https://www. forbes.com/sites/salvatorebabones/2018/02/12/china-quietly-releases-2017-provincial-gdp-figures/. Retrieved: 27 Jan 2019

Baird, N. and Kilcourse, B. (2011). Omni-channel fulfillment and the future of retail supply chain. Available at http://www. scdigest.com/assets/reps/Omni_Channel_Fulfillment.pdf.

Beck N, Rygl D (2015) Categorization of multiple channel retailing in Multi-, Cross-, and OmniChannel Retailing for retailers and retailing. J Retail Consum Serv 2:170-178 Elsevier

Bell DR, Gallino S, Moreno A (2014) How to win in an omnichannel world. Sloan Manag Rev 56:45-53

Berardi U (2017) Sustainability assessments of buildings. MDPI AG-Multidisciplinary Digital Publishing Institute

Brynjolfsson E, Hu YJ, Rahman MS (2013) Competing in the age of omnichannel retailing. MIT Sloan Manag Rev 54(4):23-29

Bucklin LP, Ramaswamy V, Majumdar SK (1996) Analyzing channel structures of business markets via the structure-output paradigm. Int J Res Mark 13(1):73-87

Chen S, Ning J (2002) Constraints on e-commerce in less developed countries: the case of China. Electron Commer Res 2(1-2):31-42

Chernyavskaya EM (2016) European international transport corridors in the context of the economic interests of the Russian Federation, St. Petersburg PhD Thesis

China-briefing.com (2016). Exporting to China: Import Tax Slashed in Cross-Border E-Commerce Zones. Available at: http://www. chinabriefing.com/news/2016/02/02/exporting-china-import-tax-slashed-cross-border-e-commerce-zones.html Retrieved: 28Jan.2019.

China's National Bureau of Statistics (2018). Annual data. Available at: http:/www.stats.gov.cn/tijs/ndsj/2018/indexeh.htm Retrieved: 20.Feb.2019

Colla E, Lapoule P (2012) E-commerce: exploring the critical success factors. Int J Retail Distrib Manag 40(11):842-864

Cooper MC, Lambert DM, Pagh JD (1997) Supply chain management: more than a new name for logistics. Int J Logist Manag 8(1):1-14

Ecommerceworldwide.com (2017) China Passport 2017. In: Cross-Border Trading Report Your guide to international e-trading Available at: https://www.imrg.org/data-and-reports/cross-border-ecommerce/. Accessed 28 Aug 2018

Eisenhardt KM (1989) Building theories from case study research. Acad Manag Rev 14(4):532-550

Emarketer.com (2015). Ecommerce Growth in Latin America Slows. Available at: https://www.emarketer.com/Article/ Ecommerce-Growth-Latin-America-Slows/1013350. Accessed 28 Aug 2018

Emarketer.com (2018). Worldwide retail and ecommerce sales: eMarketer's updated forecast and new Mcommerce estimates for 2016-2021. Available at: https://www.emarketer.com/Report/Worldwide-Retail-Ecommerce-Sales-eMarketersUpdated-Forecast-New-Mcommerce-Estimates-20162021/2002182. Accessed 28 Aug 2018

Farahani RZ, Hekmatfar M (eds) (2009) Facility location: concepts, models, algorithms and case studies. Physica-Verlag, Heidelberg

Fu W, Wang Q, Zhao X (2018) Platform-based service innovation and system design: research opportunities. Ind Manag Data Syst 118(5):975-997

Giuffrida M, Mangiaracina R, Perego A, Tumino A (2017) Cross-border B2C e-commerce to greater China and the role of logistics: a literature review. Int J Phys Distrib Logist Manag 47(9):772-795

Handfield R, Straube F, Pfohl H-C, Wieland A (2013) Trends and strategies in logistics and supply chain management: embracing global logistics complexity to drive market advantage. DW Media Group, Hamburg

Hänninen M, Smedlund A, Mitronen L (2017) Digitalization in retailing: multi-sided platforms as drivers of industry transformation. Balt J Manag 13(2):152-168

He Y, Wang X, Lin Y, Zhou F, Zhou L (2017) Sustainable decision making for joint distribution center location choice. Transp Res Part D: Transp Environ 55:202-216

Hill CWL, Hult GTM (2018) International business. Chinese People University Press, Beijing

Hilmola O-P (2018) Supply chain cases: leading authors, research themes and future direction. Palgrave Macmillan, UK Pivot Series

Hilmola OP, Tolli A (2018) Evaluation of Chinese E-commerce cost and Lead time performance to Estonia. Qual Innov Prosperity 22(1):14-26

Hongfei Y (2017) National Report on e-commerce development in China. In: Inclusive and Sustainable Industrial Development Working Paper Series, WP 17. United Nations Industrial Development Organization, Vienna

Hübner A, Wollenburg J, Holzapfel A (2016) Retail logistics in the transition from multi-channel to omni-channel. Int J Phys Distrib Logist Manag 46(6/7):562-583

International Trade Centre (2016) E-commerce in China: opportunities for Asian firms. International Trade Centre, Geneva

Jacobsen J (2014) Americans embracing online shopping. Beverage Ind 105(10):6

Jennex ME, Amoroso D, Adelakun O (2004) E-commerce infrastructure success factors for small companies in developing economies. Electron Commer Res 4(3):263-286

Jiang B, Prater E (2002) Distribution and logistics development in China: the revolution has begun. Int J Phys Distrib Logist Manag 32(9):783-798

Jiang Y, Sheu J-B, Peng Z, Yu B (2018) Hinterland patterns of China railway (CR) express in China under the belt and road initiative: a preliminary analysis. Transp Res E 119:189-201

Kayikci Y (2010) A conceptual model for intermodal freight logistics Centre location decisions. Procedia Soc Behav Sci 2(3):6297-6311

Kuglin FA (1998) Customer centered supply chain management. AMACOM (American Marketing Association), USA

Li W, Hilmola O-P, Panova Y (2019) Container Sea ports and dry ports: future CO2 emission reduction potential in China. Sustainability 11(6):1515. https://doi.org/10.3390/su11061515

Li Y, Lu M, Liu B (2014) A two-stage algorithm for the closed-loop location-inventory problem model considering returns in E-commerce. Math Probl Eng art. no. 260869. https:/www.hindawi.com/journals/mpe/2014/260869/ 
Logisticstime.com (2018). Lead time of parcels deliveries from China. Available at: http://logisticstime.com/dostavka-iz-kitaya/ sroki-dostavki-iz-kitaya/ Accessed 28 Aug 2018

Lu Z, Li X, Yang L, Yang D, Deng L (2011) Location orientation of e-shops in China's major cities based on neighborhood facilities: case studies of Shanghai, Shenzhen, Tianjin and Beijing. Dili Xuebao/Acta Geograph Sin 66(6):813-820

Lukinskiy V, Lukinskiy V (2015) Analysis of the logistics intermediaries choice methods in the supply chains. Transp Telecommun J 16(4):288-295

Lukinskiy VS (2007) Models and methods of logistics theory. SPb, Peter

Lukinskiy VS, Lukinskiy W, Malevich J, Plastuniak I, Pletneva N (2012) Models and methods of the logistics theory. SPbSUEE, St. Petersburg

Lukinskiy VS, Panova Y, Strimovskaya AV (2017) Integrated supply chain management: theories, models and methods. Logist Supply Chain Manag 3(80):20-34

Lukinskiy W, Katkova H (2014) Analysis of methods for choice of logistics intermediaries. Logist Supply Chain Manag 2(61): 49-56 (In Russian)

M.sohu.com (2017). China (Henan) Pilot Free Trade Zone. http://m.sohu.com/a/132704607_687011?from= singlemessage\&isappinstalled=0. Accessed 05 Apr 2019

Makarov AN (2011) Import substitution as an instrument of industrialization of the regional economy: an innovative aspect (on the example of the Nizhny Novgorod region). Russ External Econ Bull 5:36-40

Mercier P, Welch D, Crétenot G (2014) In omnichannel retail it's still about detail. BCG Perspect:1-4. https://www.bcg.com/ publications/2014/supply-chain-management-sourcing-procurement-omnichannel-retail-still-about-detail.aspx

Meuter ML, Bitner MJ, Ostrom AL, Brown SW (2005) Choosing among alternative service delivery modes: an investigation of customer trial of self-service technologies. J Mark 69:61-83

Miles JA (2012) Management and organization theory: a Jossey-bass reader. Jossey-Bass, San Francisco

OECD (2015) OECD urban policy reviews: China 2015. OECD Urban Policy Reviews. OECD Publishing, Paris. https://doi.org/1 0.1787/9789264230040-en

Önden I, Acar AZ, Eldemir F (2016) Evaluation of the logistics center locations using a multi-criteria spatial approach. Transport 33(2):1-13

Panova, Y. \& Hilmola, O-P. (2018). Evaluation of manufacturing unit location in Russia - European trade and logistics perspective. International Journal of Business Performance and Supply Chain Modelling, 10:1, pp. 67-89

Porter, M.E. (1990). The competitive advantage of nations. Harvard Business Review, 68:2, pp. 73-93

Rigby D (2011) The future of shopping. Harv Bus Rev 89(12):65-76

Saaty TL (1994) Fundamentals of decision making. RWS Publications, Pittsburgh

Sedyh IA (2016) Market of online trade in Russia. National Research University 'Higher School of Economics', Center of the Development, p 58

Smith A (1937) The wealth of nations. Prometheus books, USA

Tan A, Yifei Z, Dali Z, Hilmola O-P (2014) State of third party logistics providers in China. Ind Manag Data Syst 114(9):1322-1343

Tantsuyev, A. (2012). Perspectives for Logistics Clusters Development in Russia, Master degree dissertation, Massachusetts Institute of Technology, USA

Tarn JM, Yen DC, Beaumont M (2002) Exploring the rationales for ERP and SCM integration. Ind Manag Data Syst 102(1):26-34

Van Thai, V. and Grewal, D. (2005). Selecting the location of distribution centre in logistics operations: a conceptual framework and case study. Asia Pacific Journal of Marketing and Logistics, 17:3, pp.3-24

Vc.ru (2018). The e-Commerce market in Russia in 2017 exceeded 1 trillion rubles. Available at: https://vc.ru/35781-rynokinternet-torgovli-v-rossii-v-2017-godu-prevysil-1-trln-rubley. Accessed 28 July 2018

Verhoef PC, Kannan PK, Inman JJ (2015) From Multi-Channel retailing to Omni-Channel retailing. J Retail 91(2):174-181

Wei C, Asian S, Ertek G, Hu Z-H (2018) Location-based pricing and channel selection in a supply chain: a case study from the food retail industry. Ann Oper Res Article in Press

XiaoYan Q, Yong H, Qinli D, Stokes P (2012) Reverse logistics network design model based on e-commerce. Int J Organ Anal 20(2):251-261

Yin RK (2003) Case study research - design and methods, 3rd edn. Sage, Thousand Oaks

Żak, J. and Wegliński, S. (2014). The selection of the logistics center location based on MCDM/A methodology. Transportation Research Procedia, 3: 3, pp.555-564

\section{Publisher's Note}

Springer Nature remains neutral with regard to jurisdictional claims in published maps and institutional affiliations.

\section{Submit your manuscript to a SpringerOpen ${ }^{\circ}$ journal and benefit from:}

- Convenient online submission

- Rigorous peer review

- Open access: articles freely available online

- High visibility within the field

- Retaining the copyright to your article

Submit your next manuscript at $>$ springeropen.com 